\title{
Jennifer Duprey, The Aesthetics of the Ephemeral. Memory Theaters in Contemporary Barcelona, State University of New York, 20I4, 274 pp.
}

Malgrat l'efecte d'un discurs decadent generalitzat al pensament contemporani que diu que el nostre món és cada cop més inconsistent, líquid, vacu i indiferent, l'assaig que volem presentar, si no contradiu algunes d'aquestes consideracions, és una altra mostra irrefutable que el teatre català no deixa indiferents els estudiosos més enllà dels Pirineus i més enllà de l'Atlàntic: Jennifer Duprey, investigadora a la Universitat de Rutgers (NJ, USA), signa aquest treball des d'una tradició d'estudis catalans ben arrelada a la cultura científica americana.

Duprey encara la seua anàlisi del teatre català contemporani a partir d'una àmplia conceptualització de la noció «temps-memòria». Els aclariments de l'autora quant als conceptes filosòfics i crítics que utilitza, principalment els que associen estètica i condició de «l'efímer», són fonamentals per a desconfiar des del principi d'una lectura condicionada per la referència epònima L'esthétique de l'éphémère, de Christine BuciGluksmann (2006), un altre exemple de l'èxit semàntic que té aquest terme des dels anys 80 — com a mostra, L'empire de l'éphémère, de Gilles Lipovetsky (1987), conegut filòsof francès especialitzat en la teoria postmoderna-.

Partint de la dualitat (per a superar-la) desenvolupada per Buci-Gluksmann (l'efímer regeneratiu il'efímer melancòlic, associats respectivament al model de «l'espai de la moral» de Nietzsche i al model de «l'espai de la història» de Walter Benjamin), Jennifer Duprey activa la seua lectura del temps i de la memòria posicionant-se més prop de l'univers benjaminià, considerant aquest model més apte per a explicar les relacions de l'home amb l'home, des de la consciència del procés històric. Així, per a Jennifer Duprey, l'efímer no és només una germinació de la contemporaneïtat que cal identificar estèticament en les produccions artístiques, sinó sobretot un paradigma d'interpretació: d'una banda, una clau per a comprendre cóm el teatre materialitza espacialment el temps, i, d'altra, la cristal-lització, alhora fràgil i poderosa, d'una «Idea» supraestètica (Alain Badiou) que permet als lectors-espectadors «imaginar una altra societat, una altra humanitat» (p. 2). La focalització de l'anàlisi és clara: no es tracta d'un enèsim estudi d'algunes de les obres més representatives de la dramatúrgia contemporània catalana, sinó d'una lectura crítica de textos en un context ontològic reflectit en els miralls trencats de la realitat neoliberal. Els suports teòrics de Duprey no són meres destil.lacions filosofals de fenomenologia abstracta; les referències constants a Jamenson, Eagleton, Foucault, Labanyi, Arendt, Benjamin, etc., ens introdueixen en la tradició del pensament crític que recupera el necessari diàleg entre art, història, política i compromís. 
És en aquest punt de partida on resideix, creiem, la singularitat crítica i hermenèutica d'aquest assaig (en contrast amb el corpus escollit, integrat per obres ja molt conegudes de la crítica i dels lectors-espectadors), complementant les aportacions tambéfonamentals en matèria teatral de la catalanista nord-americana Sharon Feldman.

Cinc són les obres escollides per Jennifer Duprey: Olors (2000), Testament (1996) de Josep Maria Benet i Jornet, Antígona (2002) de Jordi Coca, Temptació (2004) de Carles Batlle i Forasters (2004) de Sergi Belbel. L'elecció es fa per afinitat a uns eixos temàtics preestablerts, i no a l'inrevés, en adequació amb plantejaments crítics actuals (hermenèutica de la història, fenomenologia de la memòria, (trans)culturació socioidentitària), i amb problemàtiques existencials i socials del nostre temps (devastacions morals i urbanístiques com a metàfora de la decadència humana; violència política i simbòlica; immigració; herència i transmissió del passat i de la memòria cultural, etc.). És força pertinent la justificació que fa la pròpia autora: el corpus escollit desenvolupa d'una manera específica formes del pensament utòpic (utopian thinking) que es llegeixen com a antídot principal contra un ethos corromput per la despolitització i els efectes anivelladors de la globalització cultural (p. XII). Potser no són les obres més representatives de «tota» la dramatúrgia catalana a partir dels anys 9o, sinó les obres que millor serveixen a l'objectiu de l'autora, atès que representen unes realitats socials i epistèmiques evolutives inspiradores d'aquest teatre. ¿És aquesta recerca de correspondències la que pot explicar —en part— per què no hi ha al seu corpus textos d'autoria femenina, quan, paradoxalment, la feminització de l'escriptura teatral també es desenvolupa a partir dels anys 90?

El fil roig que embasta el conjunt és la memòria, però no en sentit restringit $\mathrm{i}$ no associada només al subgènere «memòria històrica». La memòria hi apareix com a una mena de pleonasme de tot allò que interactua amb la noció d'efímer. I no és casualitat que Jennifer Duprey haja combinat ambdós conceptes al títol i subtítol del seu llibre, sent la memòria, o millor, les memòries cultural, individual, col-lectiva, històrica, els catalitzadors de les idees del seu assaig. En aquest sentit, cal també destacar la síntesi que fa l'autora a partir de dues tensions característiques de la dramatúrgia catalana: d'una banda, la "fragilitat» de les idees que vehicula, i d'altra banda, el caràcter «resistent» de l'ethos que les produeix, salvant-les, doncs, de l'agonia. Aquestes idees "fràgils», amenaçades per tot allò que és «líquid» i potencialment efímer (p. 193) corresponen als grans blocs del llibre, estructurats a partir d'una introducció general (The Aesthetics of the Ephemeral) i un repàs de la història del teatre català contemporani (The Journey in the Desert): 
(a) La progressiva desagregació de l'heretatge i la necessària preservació de la memòria cultural són algunes de les temàtiques estudiades a Olors, de Josep Maria Benet i Jornet, fent l'objecte d'estudi del capítol dos, Ruins, Loss, Rebirth;

(b) La possibilitat d'una justícia alternativa a «la justícia» serà l'eix de l'estudi d'Antígona, de Jordi Coca, al capítol tres Tragedy, Violence, Justice;

(c) La coexistència de les pluralitats culturals en un espai identitari, polítici públic confrontat a la immigració serà el punt de partida per a acarar Forasters, de Sergi Belbel i Temptació, de Carles Batlle, al capítol quatre Immigration, Displacements, Actualities;

(d) L'anàlisi de Testament, de Benet i Jornet, ocupa el darrer capítol, Inheritance, Memory, Natality, on es desenvolupen les possibilitats de continuïtat i transformació de l'heretatge intel-lectual confrontat a pressions nihilistes i polítiques.

Conclou amb una rigorosa síntesi, $A$ (Dis)functional Body Politic, on l'autora reafirma l'objectiu de la seua tesi: el teatre polític i compromès té la capacitat de donar consistència i soliditat a aquestes «idees» en estat deliqüescent, fent inclús de «l'efímer» una eina d'expressió i de materialització artística de la fragilitat.

Una darrera reflexió tancaria aquesta ressenya: la perspectiva adoptada per l'autora, fidel a una metodologia global pròpia dels cultural studies, és potser l'únic camí que permet tornar a obres "panteonitzades» en el repertori ja "clàssic» català. Són obres de fa vint, quinze anys; és doncs interessant veure cóm aquesta lectura d'un teatre nascut fa dues dècades ens parla no tant del context de producció d'aquelles obres, sinó de l'actualitat de la investigadora, del nostre temps. Això ens condueix a la pregunta òbvia: ¿quines són les diferències, doncs, entre el teatre compromès d'avui i el teatre de fa vint anys? Si la resposta apel.la a eines d'anàlisi estètica, podem tanmateix seguir interrogant-nos sobre el sentit d'un present fet de matèria efímera, ¿encara explicable a partir dels models del pensament postmodern? Llavors: ¿`’assoleix en les nostres societats la condició de "l'efímer" com una fatalitat o com auna necessitat (d'auto)comprensió? La crisi econòmica i política ha sacsejat (un poc) el procés històric català $\mathrm{i}$ ha donat lloc a espais reals aliant ciutadania $\mathrm{i}$ «utopies» de pensament polític alternatiu, però ¿són també propostes efímeres i/o «d'evaporació post-líquida»?

Aquestes preguntes obertes no formen part, evidentment, de l'objecte d'estudi d'aquest llibre (que hauria de ser traduït el més aviat possible), encara que hi són suggerides. Tanmateix, alguns elements de resposta recorren les seues pàgines, fins a transportar-nos a una conclusió on l'autora subratlla la necessitat de no oblidar la fragilitat de la condició humana, considerant, en uns dels epígrafs més atractius del llibre, que l'estat de l'home no és altra cosa que un gra efímer de sorra: «We, who are not of the desert though we live in it, are able to transform it into a human world...

Caplletra 60 (Primavera, 2016), pp. 269-272 
[...] In other words, the oases... are not places of 'relaxation', but life giving sources that let us live in the desert without becoming reconciled to it» (citació de Hannah Arendt, p. 19I).

Antonia Amo Sanchez Université d'Avignon et des Pays de Vaucluse (França) 